\title{
PENGEMBANGAN BAHAN AJAR MANDIRI POKOK BAHASAN SUHU DAN KALOR MENGGUNAKAN SOFTWARE CAMTASIA
}

\author{
Dwi Nurul Hidayah' ${ }^{1}$ an Ghery Priscylio ${ }^{2}$ \\ 1. Pendidikan Ilmu Pengetahuan Alam, Sekolah Pascasarjana Universitas Pendidikan \\ Indonesia, Jalan Setiabudhi No. 229 Isola Sukasari Kota Bandung Jawa Barat 40154 \\ Indonesia \\ E-mail: dwinurulhidayah944@gmail.com
}

\begin{abstract}
ABSTRAK
Ketuntasan belajar merupakan salah satu masalah dalam pembelajaran Fisika. Hasil wawancara dengan guru dan pemberian angket kepada 22 siswa di salah satu sekolah di kota Malang didapatkan data bahwa 72,70\% siswa tidak dapat menangkap materi pembelajaran dalam sekali penjelasan, maka perlu keberulangan dalam penyampaian penjelasan materi. Hasil angket tingkat penguasaan konsep siswa dalam satu pertemuan rata-rata 69.72\%. Penelitian ini bertujuan untuk menghasilkan bahan ajar mandiri pada pokok bahasan suhu dan kalor menggunakan software Camtasia. Penelitian ini menggunakan metode penelitian Research and Development $(R \& D)$. Model pengembangan yang digunakan dalam penelitian pengembangan bahan ajar mandiri berbantuan software camtasia materi Suhu dan Kalor untuk Siswa SMA mengadaptasi model pengembangan Four-D Models oleh Thiagarajan yang telah dimodifikasi menjadi 3D. Tahapan model pengembangan Four-D Model yang terdiri dari empat tahap dimodifikasi menjadi tiga tahapan yaitu tahap pendefinisian (define), tahap perancangan (design), tahap pengembangan (develop). Berdasarkan analisis data keseluruhan uji validasi oleh 3 validator yaitu 1 dosen dan 2 guru diperoleh nilai rata-rata sebesar 3.285. jika disesuaikan dengan kriteria yang telah ditentukan, maka nilai tersebut dinyatakan valid dan layak.
\end{abstract}

Kata kunci: Bahan Ajar Mandiri, Suhu dan Kalor, 4-D Models, Camtasia, Pendidikan Fisika

\begin{abstract}
Completeness of learning is one of the problems in learning of physics. The results of interviews with teachers and the provision of questionnaires to 22 students in one school in the city of Malang obtained data that $72.70 \%$ of students could not capture the learning material in one explanation, it was necessary to repeat the delivery of material explanations. The results of the questionnaire level of students' mastery of concepts in one meeting averaged $69.72 \%$. This research aims to generate an independent teaching materials on the subject of temperature and heat using Camtasia software. Research and development was used as method of the study. The development model used in the Research of the development (R\&D) of independent teaching materials assisted by camtasia software for temperature and heat material for high school students adapted the development model of Four-D Models by Thiagarajan which was modified to 3D. The stages of the Four-D Model development model which consists of four modified stages into three stages i.e define, design, develop. Based on the overall data analysis validation test by 3 validators namely 1 lecturer and 2 teachers obtained an average value of 3,285. if adjusted to the criteria that have been determined, then the value is declared valid and feasible.
\end{abstract}

Keywords: Independent Teaching Materials, Temperature and Heat, 4-D Models, Camtasia, Physic Education

Received: 29 Januari 2019; Accepted: 1 Februari 2019; Published: 4 Februari 2019 


\section{PENDAHULUAN}

Fisika merupakan cabang sains atau ilmu pengetahuan paling fundemantal karena merupakan dasar dari semua bidang sains (Purwanto, 2012; Tripler, 1998). Fisika merupakan pelajaran yang memberikan pengetahuan tentang alam semesta untuk berlatih berpikir dan bernalar, melalui kemampuan penalaran seseorang yang terus dilatih sehingga semakin berkembang, maka orang tersebut akan bertambah daya pikir dan pengetahuannya (Campbell, 2007; Kim, Minkee, \& Ogawa, 2007; Kultawanicha Kulachai, 2015). Hal ini menunjukkan arti pentingnya belajar Fisika. Pada pembelajaran ada tiga komponen yang terlibat yaitu guru , siswa dan bahan ajar (Anwar, 2017). Bahan ajar menjadi salah satu faktor penting dalam pembelajaran. Kondisi dilapangan saat ini bahan ajar masih kurang bervariatif (Priscylio, Rochintaniawati, \& Anwar, 2018). Bahan ajar yang tersedia saat ini masih kurang menarik bagi siswa sehingga menyebabkan berkurangnya motivasi dan semangat belajar siswa (Ghery Priscylio, Mulyadi, 2018).

Peraturan pemerintah Nomor 65 Tahun 2013 tentang Standar Proses menyatakan bahwa salah satu prinsip pembelajaran yang digunakan dalam kurikulum 2013 adalah pemanfaatan teknologi informasi dan komunikasi untuk meningkatkan efisiensi dan efektivitas pembelajaran. Proses pembelajaran pada suatu Kompetensi Dasar, terdapat banyak permasalahan. Tidak semua siswa dapat menangkap pelajaran dengan waktu yang sama karena tingkat intelektual setiap siswa berbeda. Dari hasil wawancara dengan guru dan pemberian angket kepada 22 siswa pada salah satu sekolah di kota Malang didapatkan data bahwa 72,70 \% siswa tidak dapat menangkap materi pembelajaran dalam sekali penjelasan, perlu keberulangan dalam penyampaian penjelasan materi. Dari hasil angket juga diperoleh data sebagai berikut, tingkat penguasaan konsep siswa dalam satu pertemuan rata-rata $69.72 \%$ dan guru tidak dapat membimbing siswa di luar jam pelajaran. Pembimbingan guru hanya berlangsung di kelas dengan waktu yang terbatas ketika diskusi berlangsung dan belum ada bahan ajar mandiri untuk siswa. Kehadiran Kurikulum 2013 menjawab permasalahan kesulitan siswa melalui Pendekatan scientific antara lain memiliki langkah-langkah pokok yaitu mengamati, menanya, menalar, mencoba, mengolah, menyajikan, menyimpulkan dan mengkomunikasikan (Ningrum, 2009).

Pengembangan kurikulum 2013 difokuskan kepada pembentukan kompetensi dan karakter para peserta didik yang berupa paduan pengetahuan, keterampilan, dan sikap yang dapat didemonstrasikan peserta didik sebagai wujud pemahaman terhadap konsep yang dipelajarinya secara kontekstual (Puspitasari, 2013; Sardiman, 2001). Oleh karena itu, pembelajaran harus diawali dengan lingkungan terdekat siswa. Alasan yang dikemukakan di atas maka perlu diadakan penelitian dengan tema pengembangan bahan ajar mandiri berbantuan software camtasia pada pokok bahasan suhu dan kalor untuk siswa SMA serta mendiskripsikan kelayakan bahan ajar mandiri berbantuan software Camtasia tersebut.

\section{METODE PENELITIAN (CAMBRIA, ALL CAPS, 12 PT, BOLD)}

Pada penelitian ini penulis menggunakan metode penelitian Research and Development (R\&D) (Sugiyono, 2011; Sukmadinata, 2009). Model pengembangan yang digunakan dalam penelitian pengembangan bahan ajar mandiri siswa berbantuan software camtasia materi Suhu dan Kalor untuk Siswa SMA mengadaptasi model pengembangan Four- $D$ 
Model yang telah disederhanakan menjadi 3D (Thiagarajan, S., Semmel, D.S., \& Semmel, 1974). Thiagarajan memaparkan mengenai tahapan model pengembangan Four-D Model yang terdiri dari 3 tahap. Tahapan tersebut meliputi tahap pendefinisian (define), tahap perancangan (design), tahap pengembangan (develop). Penentuan tempat penelitian di SMA Brawijaya Smart School didasarkan atas kurikulum yang dipakai merupakan kurikulum 2013, sedang dalam pembelajaran suhu dan kalor, serta perolehan data bahwa belum ada bahan ajar mandiri yang disediakan oleh guru kepada siswa. Uji validasi dilakukan oleh 1 dosen Fisika Universitas Negeri Malang, 1 guru di SMA Brawijaya Smart School, dan 1 guru di MAN Kota Batu. Sedangkan untuk uji terbatas dilakukan pada 22 siswa kelas X di SMA Brawijaya Smart School. Instrumen penelitian yang digunakan dalam studi pendahuluan berupa angket dan wawancara. Studi pendahuluan dilakukan dengan cara menyebarkan angket kepada siswa dan wawancara 1 guru pada salah satu sekolah di kota Malang. Uji validasi dan uji terbatas menggunakan (Sugiyono, 2014) angket. Teknik analisis data untuk menganalisis data hasil penilaian kelayakan adalah dengan perhitungan rata-rata untuk data kuantitatif.
Pada penelitian ini, skala penilaian yang digunakan adalah 1 sampai 4, dimana 1 sebagai skor terendah dan 4 merupakan skor tertinggi. Penentuan rentang dapat diketahui melalui rentang skor tertinggi dikurangi skor terendah dibagi dengan skor tertinggi. Berdasarkan penentuan rentang tersebut diperoleh rentang 0,75 . Sedangkan data kualitatif berupa saran dan komentar validator serta siswa digunakan sebagai pertimbangan untuk revisi produk(Arikunto, 2008; Latisma, 2011; Mudjijo, 1995).

\section{HASIL DAN PEMBAHASAN}

Bahan ajar mandiri berbantuan software camtasia merupakan kombinasi dari 3 software yaitu Power Point yang di camtasiakan kemudian hasil rekaman akan di input ke dalam autoplay. Bahan ajar mandiri ini terdiri dari video pembahasan materi dengan jumlah 5 sub bab, 5 video pembahasan soal latihan, dan 5 video praktikum atau demonstrasi. Bahan ajar mandiri ini juga terdapat soal evaluasi untuk mengukur keberhasilan dari pembelajaran mandiri oleh siswa, sehingga guru bisa mengetahui dan menindak lanjuti hasil tersebut. Tampilan produk bahan ajar mandiri bisa dilihat pada Gambar 1,2 dan 3 .

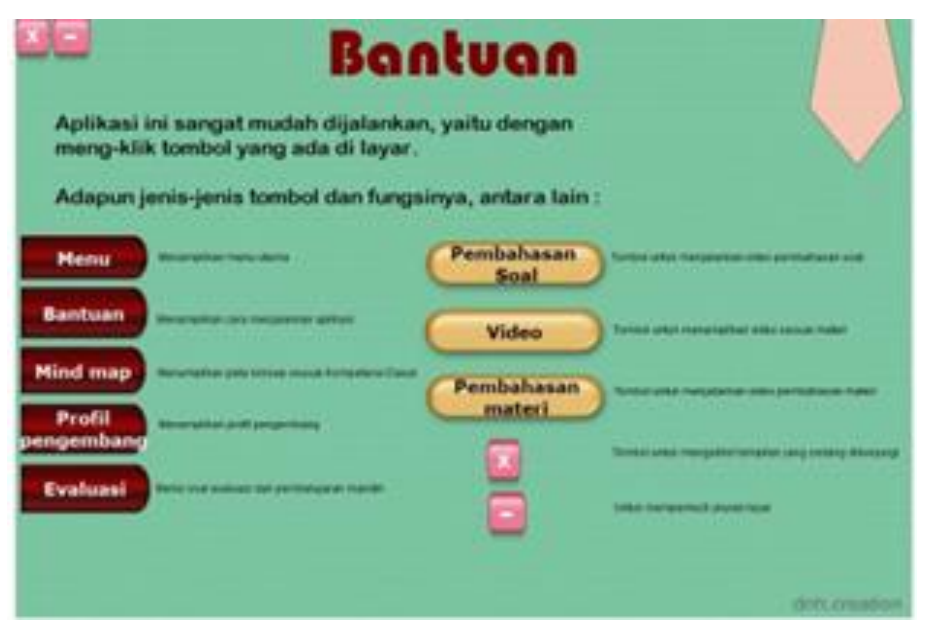

Gambar 1. Tampilan Halaman Bantuan 


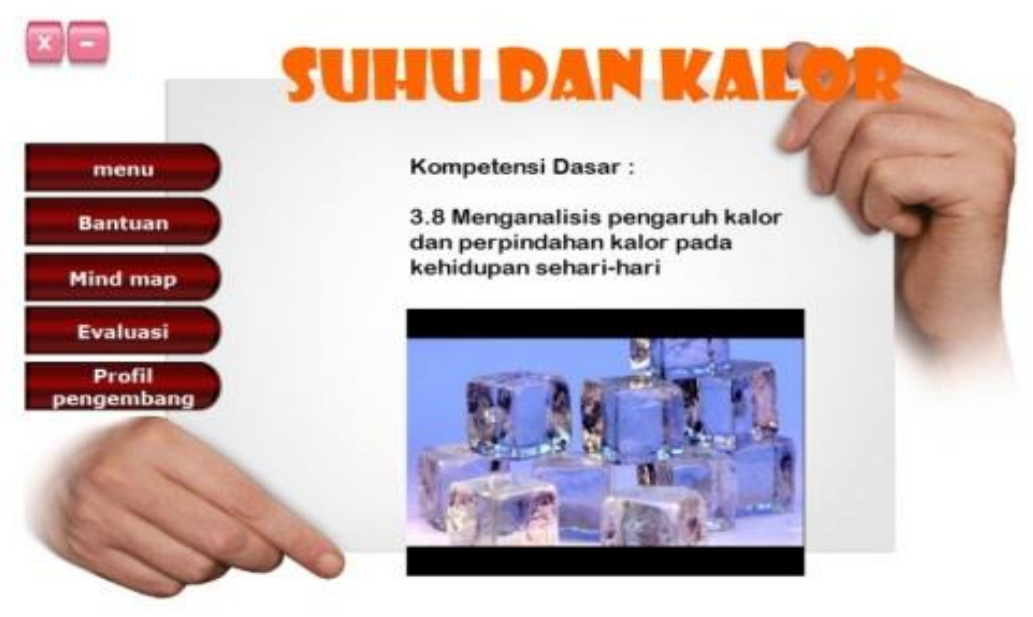

Gambar 2. Tampilan Halaman Menu
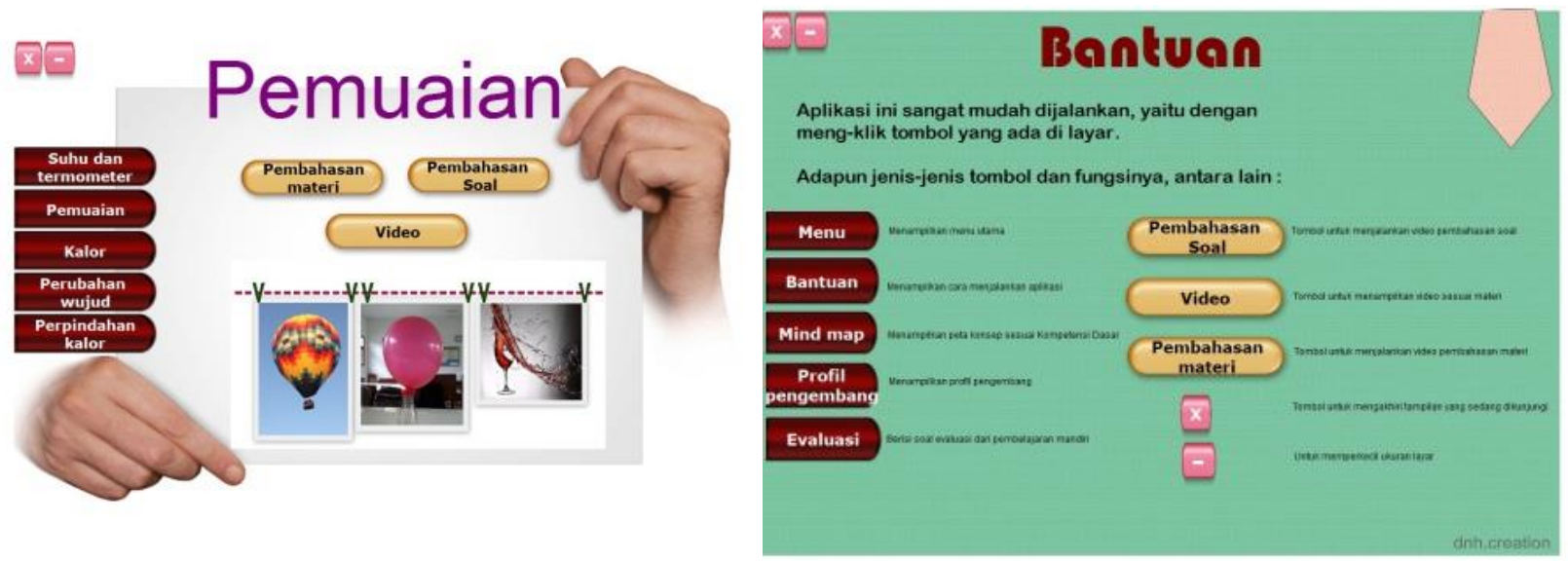

Gambar 3. Konten Materi Pada Bahan Ajar Mandiri

Jika dikaji berdasarkan teori, bahan ajar mempunyai beberapa karakteristik, antara lain mampu membelajarkan peserta didik, mampu menunjang motivasi siswa, mampu membelajarkan sendiri siswa dan bersifat lengkap (Benli, 2011; Çelika, 2010; RE, 2009).Hal ini sudah dipenuhi oleh pengembang dalam melakukan pengembangan bahan ajar mandiri berbantuan software camtasia pokok bahasan suhu dan kalor untuk siswa SMA. Berdasarkan CTML, dengan menambahkan gambar pada bahan ajar dapat mendukung pembelajaran karena informasi kemudian akan dikoding dan disimpan berupa kode verbal dan kode gambar (Chioua, 2012; Ildziko, 2013; Korakakis, 2012). Bahan ajar mandiri berbantuan software camtasia dikembangkan berdasarkan kurikulum 2013, Kompetensi dasar dari materi Suhu dan Kalor adalah sebagai berikut; (3.8) Menganalisis pengaruh kalor dan perpindahan kalor pada kehidupan sehari-hari, dan (4.8) Merencanakan dan melaksanakan percobaan untuk menyelidiki karakteristik termal suatu bahan, terutama kapasitas dan konduktivitas kalor. Adapun bab suhu dan kalor dibagi menjadi 5 sub bab yaitu suhu dan thermometer, pemuaian, kalor, perubahan wujud, serta perpindahan kalor. 
Setiap sub bab dilengkapi dengan video pembahasan materi, video pembahasan soal, dan video pendukung. Angka berdasarkan analisis data keseluruhan validasi menunjukkan bahwa bahan ajar valid, menarik, dan layak.

Adapun teori yang mengemukakan bahan ajar dapat membangkitkan minat belajar siswa dan mampu memberikan kesempatan pada siswa untuk berlatih. (Masna, 2015; Mirela \& Popa, 2015; Moroni, 2013; Onorotoa, Paquale \& Ambrossia, 2014). Sehingga, bahan ajar mampu digunakan secara mandiri serta dapat membangkitkan minat belajar siswa. Jika mengacu pada saran dan komentar siswa serta penilaian yang dilakukan oleh siswa melalui uji terbatas, maka bahan ajar mandiri berbantuan software camtasia yang dikembangkan sudah memotivasi siswa untuk belajar dengan tampilan menarik dan dapat memudahkan siswa untuk belajar dimana saja dan kapan saja sesuai dengan kecepatan masing-masing siswa. Output dari bahan ajar mandiri berbantuan software camtasia adalah berupa soft file autorn yang bisa dijalankan di komputer. Pada bahan ajar tersebut juga terdapat soal evaluasi untuk mengetahui bagaimana keberhasilan siswa dalam belajar mandiri. Soal evaluasi terdiri dari 30 soal dengan tingkat kelulusan $60 \%$. Jadi, setelah pengerjaan soal selesai, siswa secara langsung mendapatkan feedback berupa skor dan review jawaban yang salah.

Pengembangan bahan ajar mandiri berbantuan Camtasia sebelumnya sudah pernah dikembangkan oleh Fahmi dalam penelitiannya yang berfokus pada pengembangan media pembelajaran berupa video pembelajaran (Mbulu, 2001). Namun, peneliti akan melakukan inovasi penyampaian secara konstekstual dan disesuaikan dengan kurikulum 2013, sehingga siswa diharapkan lebih mudah memahami materi dengan baik.
Hasil penelitian mengemukakan bahwa siswa akan belajar dengan baik jika apa yang dipelajari terkait dengan apa yang telah diketahui dan kegiatan atau peristiwa yang terjadi di sekelilingnya (Parkay, Forrest, 2001). Hal inilah yang menjadi dasar pengembangan bahan ajar mandiri berbantuan software camtasia, sehingga penyampaian materi dalam bahan ajar mandiri ini selalu diawali dengan peristiwa yang dekat dengan lingkungan siswa.

Berdasarkan analisis hasil validasi isi oleh 3 validator, komponen video pembahasan materi didapatkan skor rata-rata 3.21 dengan kategori valid. Video pembahasan soal didapatkan skor rata-rata 3.028, angka ini masuk pada kriteria valid. Untuk komponen prinsip pengembangan produk dihasilkan skor rata-rata 3.27 yang dinyatakan valid, kemudian untuk skor ratarata soal latihan adalah 3.028 yang dinyatakan valid. Sedangkan untuk peta konsep dihasilkan skor rata-rata 3.33, angka ini masuk kriteria valid. Sehingga secara keseluruhan, hasil validasi isi dari ketiga validator diperoleh skor rata-rata 3.31 nilai tersebut masuk kriteria valid. Berdasarkan analisis hasil validasi konstruk, komponen menu mendapatkan skor rata-rata 3.408 dengan kategori valid. Untuk komponen video pembahasan materi mendapatkan skor rata-rata 3.18, angka ini menunjukkan bahwa video pembahasan soal dinyatakan layak. Untuk komponen video pembahasan soal mendapatkan skor 3.23 dan masuk dalam kategori layak (Trianto, 2012). Sedangkan komponen soal latihan mendapatkan skor rata-rata 3.22 dengan kategori layak. Dengan demikian, rata-rata keseluruhan hasil validasi konstruk didapatkan skor rata-rata 3.25 dengan kategori layak untuk diterapkan pada siswa. Analisis data keseluruhan uji coba terbatas kepada 22 siswa kelas X di SMA Brawijaya Smart School diperoleh nilai rata-rata sebesar 3.25. 
Tabel 1. Analisis Data Keseluruhan Validasi

\begin{tabular}{lccl}
\hline No. & Subjek & $\begin{array}{c}\text { Rerata total butir pertanyaan } \\
\text { masing-masing kelompok }\end{array}$ & Kriteria \\
\hline 1. & Validator isi & 3.31 & Layak \\
\hline 2. & Validasi konstruk & 3.25 & Layak \\
\hline Rata-rata keseluruhan & 3.285 & Layak \\
\hline
\end{tabular}

Tabel 2. Analisis Data Keseluruhan Uji Coba Terbatas

\begin{tabular}{lcc}
\hline No. & Subjek & $\begin{array}{c}\text { Rerata Total Butir Pertanyaan masing- } \\
\text { masing kelompok }\end{array}$ \\
\hline 1. & Uji coba pengguna & 3.25 \\
\hline Rata-rata keseluruhan & 3.25 \\
\hline
\end{tabular}

Adapun beberapa revisi sesuai saran dan komentar yang diberikan oleh validator dan siswa seperti suara narrator harus diperkeras, pembesaran font, dan perbaikan di bagian Bahasa yang digunakan dalam soal. Tahap akhir dari pengembangan bahan ajar mandiri ini adalah pendiseminasian. Bahan ajar mandiri berbantuan software camtasia pokok bahasan suhu dan kalor sudah disebarkan ke guru fisika di SMA Brwaijaya Smart School, MAN Kota Batu, blogger peneliti, dan web Fisika Universitas Negeri Malang. Penyebarluasan bahan ajar mandiri ini diharapkan memberikan manfaat kepada pihak yang menerima produk ini.

Kekuatan produk bahan ajar mandiri berbantuan software camtasia pokok bahasan suhu dan kalor adalah pertama, kemasan produk yang dibagi menjadi page tiap sub bab sehingga dalam sub bab suhu dan thermometer sudah melingkupi video pembahasan materi, pembahasan soal, dan video pendukung yang dimabil dari internet. Kedua, produk bahan ajar mandiri berbantuan software camtasia sangat mudah dijalankan sehingga tidak perlu buku tutorial dalam penggunaannya. Ketiga, produk tersebut terdapat soal evaluasi yang memberikan feedback secara langsung kepada siswa, sehingga siswa dapat mengukur presentase penguasaan materi dari hasil belajar mandiri, serta bahan ajar mandiri berbentuk soft file sehingga mudah dibawa sekaligus disimpan dalam flashdisk untuk dipelajari kapan saja dan dimana saja.

Kelemahan produk bahan ajar mandiri berbantuan software camtasia pokok bahasan suhu dan kalor adalah untuk membuka soal evaluasi, maka siswa harus mempunyai aplikasi flash player. Untuk feedback soal evaluasi belum ada pembahasan jawaban yang benar, jadi hanya ada koreksi pilihan jawaban yang tepat dan rekapan hasil pekerjaan siswa.

\section{KESIMPULAN}

Hasil analisis keseluruhan validasi oleh 3 validator sudah menunjukkan bahwa bahan ajar mandiri yang dikembangkan dinyatakan valid dan layak. Sedangkan untuk penyempurnaan bahan ajar mandiri, sudah dilakukan revisi beberapa bagian sesuai dengan saran dan komentar dari validator sekaligus siswa. Jika dikaji berdasarkan teori, bahan ajar mempunyai beberapa karakteristik, antara lain mampu membelajarkan peserta didik, mampu menunjang motivasi siswa, 
mampu membelajarkan sendiri siswa dan bersifat lengkap (Mirela \& Popa, 2015; Moroni, 2013; Onorotoa, Paquale \& Ambrossia, 2014; Pawana, Suaharsono, \& Kirna, 2014). Hal ini sudah dipenuhi oleh pengembang dalam melakukan pengembangan bahan ajar mandiri berbantuan software camtasia pokok bahasan suhu dan kalor untuk siswa SMA.

Angka berdasarkan analisis data keseluruhan validasi menunjukkan bahwa bahan ajar valid, menarik, dan layak. Adapun teori yang dikemukakan oleh Pannen dalam bukunya, bahan ajar dapat membangkitkan minat belajar siswa dan mampu memberikan kesempatan pada siswa untuk berlatih. Jadi, bahan ajar mampu digunakan secara mandiri serta dapat membangkitkan minat belajar siswa. Jika mengacu pada saran dan komentar siswa serta penilaian yang dilakukan oleh siswa melalui uji terbatas, maka bahan ajar mandiri berbantuan software camtasia yang dikembangkan sudah memotivasi siswa untuk belajar dengan tampilan menarik dan dapat memudahkan siswa untuk belajar dimana saja dan kapan saja sesuai dengan kecepatan masing-masing siswa.

\section{DAFTAR PUSTAKA}

Anwar, S. (2017). Pengolahan Bahan Ajar.
$\begin{aligned} & \text { Bandung: Universitas } \\ & \text { Indonesia. }\end{aligned}$

Arikunto, S. (2008). Dasar-Dasar Evaluasi Pendidikan. Jakarta: Bumi Aksara.

Benli, E. et. al. (2011). The effects of technology teaching materials on students' image of Scientists. Social and Behavioral Sciences, Vol.15, 2371-2376.

Campbell, J. (2007). Using Metacogs to Collaborate with Students to improve Teaching and Learning in Physics. Educational Insights, 11(2).

Çelika, L. (2010). Evaluation of the views of pre-service teachers taught with Moodle during the course named "instructional technology and material design" on the use of teaching materials. Social and Behavioral Sciences, 9.

Chioua, C.-C. e. all. (2012). Effect of Novak Colorful Concept Map with Digital Teaching Materials on Student Academic Achievement. Social and Behavioral Sciences, 64, $192-201$.

Ghery Priscylio, Mulyadi, D. R. (2018). Needs of integrated science experiment student worksheet in junior high school to improve students science process skills. In International Conference on Mathematics and Science Education (ICMSCE).

Ildziko, schabo. (2013). Harmonizing Diagnostic Assessment, National Frameworks and Teaching Materials in the Hungarian Education System. Social and Behavioral Sciences, 81, 50 - 54.

Kim, Minkee, \& Ogawa, M. (2007). Development of An instrument for measuring effective factore regarding conceptual understanding in High school physiscs. Journal of Korea Association of Research in Science Education, 27(449).

Korakakis, G. et. all. (2012). The impact of 3D visualization types in instructional multimedia applications for teaching science. Social and Behavioral Science, 31, 145-149.

Kultawanicha Kulachai. (2015). A Proposed Model of Connectivism Learning Using Cloud-based Virtual Classroom to Enhance Information Literacy and Information Literacy Self-efficacy for Undergraduate Students. Social and Behavioral Sciences, 191, 87-92.

Latisma. (2011). Evaluasi Pendidikan. Padang: UNP Press.

Masna, A. A. (2015). Pengembangan Bahan Ajar Pop-Up Mata Pelajaran IPA Untuk Anak Tunarungu Kelas IV SDLB B di Yogyakarta. 
Universitas Negeri Yogyakarta. Universitas Negeri Yogyakarta.

Mbulu, J. (2001). Pendekatan dan Bentuk Pengajaran Individual. Kota Malang: Universitas Negeri Malang.

Mirela \& Popa, C. (2015). Development of Teaching Materials and Utilization of Web 2.0 in Japanese Language Teaching and Learning. Social and Behavioral Sciences, $182,325-330$.

Moroni, G. e. all. (2013). Version Management of the Dynamic Teaching Materials. ComMoroni, George.et Allputer Science, 22, 430-439.

Mudjijo. (1995). Tes Hasil Belajar. Jakarta: Bumi Aksara.

Ningrum, E. (2009). Pendekatan Kontekstual (Contextual Teaching and Learning). Karawang.

Onorotoa, Paquale \& Ambrossia, A. De. (2014). Laboratory and Multimedia In Science Teaching: Experiments About Magnetic Force. Social and Behavioral Sciences, (116), 1280 - 1287.

Parkay, Forrest, D. (2001). Menjadi Seorang Guru. Jakarta: PT. Indeks Jakarta.

Pawana, M. G., Suaharsono, N., \& Kirna, I. M. (2014). Pengembangan Multimedia Interaktif Berbasis Proyek Dengan Model Addie Pada Materi Pemrograman Web Siswa Kelas X Semester Genap di SMK Negeri 3 Singaraja. E-Journal Program Pascasarjana Universitas Pendidikan Ganesha, 4, 7.

Priscylio, G., Rochintaniawati, D., \& Anwar, S. (2018). Needs of integrated science textbook for junior high school based on learning style ( descriptive research ). In International Conference on Mathematics and Science Education (ICMScE). Bandung: Universitas Pendidikan Indonesia.

Purwanto, A. (2012). Berpikir Logis Siswa Sma Negeri 8 Kota Bengkulu Dengan
Menerapkan Model Inkuiri Terbimbing Dalam Pembelajaran Fisika. Jurnal Exacta ISSN .1412-3617, 10(2).

Puspitasari, A. (2013). Self Regulated Learning Ditinjau dari Goal Orientation. Universitas Negeri Semarang.

RE, M. (2009). Multimedia learning (2nd ed.). New York: Cambridge UniversityPress.

Sardiman. (2001). Interaksi dan Motivasi BelajarMengajar. Jakarta: PT Raja Grapindo Persada.

Sugiyono. (2011). Metode peneitian kombinasi (Mixed Methods). Bandung: Alfa Beta.

Sugiyono. (2014). Metode Penelitian Pendidikan. Bandung: Alfa Beta.

Sukmadinata, N. S. (2009). Metode Penelitian Pendidikan. Bandung: PT. Remaja Rosdakarya.

Thiagarajan, S., Semmel, D.S., \& Semmel, M. . (1974). Instructional Development for Training Teachers of Exceptional Children.Minneapolis. Minnesota: Leadership Training Institute/Special Education, University of Minnesota.

Trianto. (2012). Model Pembelajaran Terpadu. Jakarta: Bumi Aksara.

Tripler. (1998). Fisika untuk Sains dan Teknik Edisi Ketiga Jilid I. Jakarta: Erlangga. 

dan Kalor Menggunakan Software Camtasia 